\title{
International Curriculum Comparison in Vocational Education and Training: A Collaborative Development of an Analysis Instrument
}

\author{
Pujun Chen ${ }^{1 \star}$, Anastasia Goncharova ${ }^{2}$, Matthias Pilz ${ }^{1}$, Dietmar \\ Frommberger ${ }^{2}$, Junmin $\mathrm{Li}^{1}$, Olga Romanova ${ }^{3}$, Yueru Lin ${ }^{4}$ \\ ${ }^{1}$ University of Cologne Chair of Economics and Business Education, \\ Herbert-Lewin-Str. 2, 50931 Cologne, Germany \\ ${ }^{2}$ Osnabrück University Chair of Vocational and Business Education, \\ Katharinenstr. 24, 49078 Osnabrück, Germany \\ ${ }^{3}$ Higher School of Economics Institute of Education Centre for Vocational Education and \\ Skills Development, Potapovsky Pereulok 16, 101000 Moscow, Russia \\ ${ }^{4}$ East China Normal University Institute of Vocational and Adult Education, \\ N. Zhongshan Rd.3663, 200062 Shanghai, China
}

Received: 15 December 2020, Accepted: 28 March 2021

\begin{abstract}
Context: International comparative research on Vocational Education and Training (VET) is gaining importance, as global cooperation and mutual learning in VET grows. However, it is characterized by a high degree of complexity, due on one hand, to the heterogeneity of the VET sector, and on the other hand to the unique challenges of international comparisons. In addition, comparative research projects are increasingly conducted in the form of cross-border collaborations, which have their own particular organizational and methodological considerations, opportunities, and challenges. This paper presents an example of a cooperative research process, aimed at investigating the complex phenomenon of the competence-based approach in Russian and Chinese VET. In providing an example of developing an instrument for curriculum analysis and comparison, we discuss and reflect on the methodological and organizational peculiarities and challenges of the research process conducted collaboratively by an international team.
\end{abstract}

*Corresponding author: pujun.chen@uni-koeln.de 
Method: The instrument for analysis and comparison of curricular documents, was developed in an iterative multi-stage process, combining deductive and inductive steps. The embeddedness of the elements of a competence-based approach in curricular documents is investigated, using qualitative content analysis. To develop a coding frame, we started with a comprehensive partially systematic literature review of international, Russian and Chinese discourses on competence-based curricula. The frame was built on the selected model of competence-based education, and on accumulated results of the literature analysis of national discourses. Furthermore, during the first coding process, an iterative adaptation of the developed instrument took place.

Results: The result of this process was the development of an analysis instrument which, on the one hand, is well-adapted to each national context and, on the other hand, allows a comparison of results along the same dimensions of analysis, in our case, elements of the competence-based approach in curriculum.

Conclusion: Developing an analysis framework for a cross-cultural comparative investigation of such a diffuse and heterogeneous construct as the competence-based approach, can pose a methodological challenge for an international team of researchers. However, an effective application of own team resources such as proficiency in different languages, insider and outsider perspectives, along with continuous intensive communication and a flexible, iterative research process, allows development of a well-adapted analysis instrument for international comparison.

Keywords: International Comparative Research, Vocational Education and Training, VET, Competence-Based Education, Curriculum, Analysis Instrument

\section{Introduction}

The interest in the experience of other countries in the educational field has a long tradition; however, globalization has been continuously intensifying the pursuit of a more profound understanding of different education systems. Governments support and invest in development of various forms of international cooperation and partnerships in the educational fields, in order to exchange good practices, or bring their educational know-how to foreign markets (Lauterbach, 2003a; McDonald, 2012). Playing a crucial role in workforce preparation for the labor market and, therefore, in the country's economic prosperity, the sector of Vocational Education and Training (VET), as could be expected, is gaining a lot of interest as a sphere of cooperation and mutual learning. In light of these processes, the importance of comparative research on VET is growing (Lauterbach \& Mitter, 2018). This research contributes to a deeper understanding of different VET approaches and systems, their functioning, 
development, stakeholders, relationships to general and higher education and so forth, providing the necessary foundation for further international cooperation and research processes in the VET field, and valuable information for political decisions (Lauterbach, 2003a). In addition, one of the further intentions associated with comparative (VET) research is to gain lessons from successful practices abroad in order to improve own education system (Phillips, 2009).

The international VET field is far more heterogeneous than general education, often with very different organizational forms, curriculum approaches, constellations of involved actors and modes of regulation, around the world (Billett, 2011; Pilz \& Li, 2020). The variety of terms used to describe this educational sector reflects this diversity, among which are technical and vocational education and training, technical-vocational education, further education and training, vocational and technical education, or career and technical education (MacKenzie \& Polvere, 2009). In some national contexts, the field of VET is clearly defined, while in others, there is no clear distinction from other fields of education or spheres of workforce preparation (Grollmann, 2009). Fischer (2020) points out that terms representing comparable facts, can be missing in different national contexts, while in some cases, the same words can be used to define different elements of reality. Consequently, international comparative research in the field of VET is characterized by great complexity. Researchers face various methodological challenges and organizational problems, on one hand specific to international comparative educational studies and, on the other connected to the VET sector's described heterogeneity. Consequently, obtaining comprehensive, transparent and comparative research results, becomes more challenging when VET systems of different countries are addressed in the research (Pilz, 2012).

At the same time, some researchers point out that comparative VET research is still a relatively new (sub-)discipline, where conceptual and methodological approaches are not yet well developed (Evans, 2020; Lauterbach, 2003b; Lauterbach \& Mitter, 1998; Pilz \& Li, 2020). In this regard, Lauterbach (2018a) critically points out that there is still a tendency to classify different national systems of VET through judgmental ethnocentric perspective evaluation, with broad structuring criteria in comparative VET research. Such an isolated analysis of specific factors can lead to the creation and reinforcement of stereotypes. Frommberger (2000) underlines, that the value of international comparison lies not only in a simple juxtaposition of the national systems, based on the common denominator and production of the general conclusions valid and applicable across borders, but especially in the interesting findings resulting from the identification of differences (Frommberger, 2000). A cross-border exchange between researchers through the analysis process, particularly during the interpretation of results, should facilitate international comparison (Frommberger, 2000).

Against the background of Frommberger's considerations, in recent years a positive development in the organization of comparative investigations, which allows a more efficient 
and fruitful exchange between researchers, can be identified. More and more comparative VET research projects are conducted cooperatively by research teams from different countries rather than by researchers from one state (Pilz et al., 2020). Methodological approaches of such studies are usually different. Combining different expertise, external and internal perspectives on VET systems or aspects thereof, benefits the quality of the research, and helps to overcome ethnocentric perspectives. However, the organizational, cultural and linguistic diversity in such teams usually requires a more complex research process, and has specific methodological implications.

In this paper, we present an example of the research process in international comparative research on VET, conducted cooperatively by a team of researchers from three different countries. Taking it as an example, in this paper we aim to describe and to reflect how, under the condition of great complexity of VET as a research subject, an analysis instrument can be cooperatively developed, which can be applied for an international comparative study and, at the same time, be nationally adapted. This paper will start with a presentation of the overall research context within which the presented analysis framework was developed. After, central theoretical concepts of the research will be outlined. Further, the development and adaptation process of the analysis framework will be presented. Finally, we will discuss the lessons we learned from our experience. Therefore, this paper contributes to discussion of the methodology of comparative research. The state of research into this topic as well as a presentation of the analysis results of the study are not within the scope of this paper.

\section{Research Context}

This paper presents a part of the comparative study conducted within an international research project on the competence-based approach in commercial VET. Within the framework of the project, five universities from China, Germany and Russia are participating in the research collaboration, which is: Conducting an international comparative study of the competence-based approach in commercial VET. In China and Russia, the competencebased approach has been introduced as part of the VET modernization policies in recent years. This research project aims to investigate whether the envisaged reform intentions are successfully incorporated in practice in both countries. Therefore, two central consecutive research questions of the whole research project were formulated:

1. Which elements of the competence-based approach are established in didactic-curricular planning of educational processes (intended curriculum, see Section 3)?

2. To what extent is this planning realized during teaching and learning processes in the classroom (implemented curriculum, see Section 3)? 
The research results should contribute to a better understanding of the development and the implementation of competence-based approach in VET curricula in both countries. Based on these research results, recommendations for the further development of competencebased curricula will be elaborated.

In the context of the research project, the competence-based approach serves therefore as the tertium comparationis for comparing VET of China and Russia. Tertium comparationis refers to the similarity of different elements to be compared, and is considered a prerequisite for systematic comparison (Kosmützky et al., 2020; Parreira do Amaral, 2015; Raivola, 1985). Following the central research questions, the meta tertium comparationis is further divided into two sub-elements: (1) Embeddedness of the elements of the competence-based approach in VET curricular documents, and (2) implementation in teaching-learning processes in a classroom. Accordingly, the research processes are designed in two phases (see Figure 1).

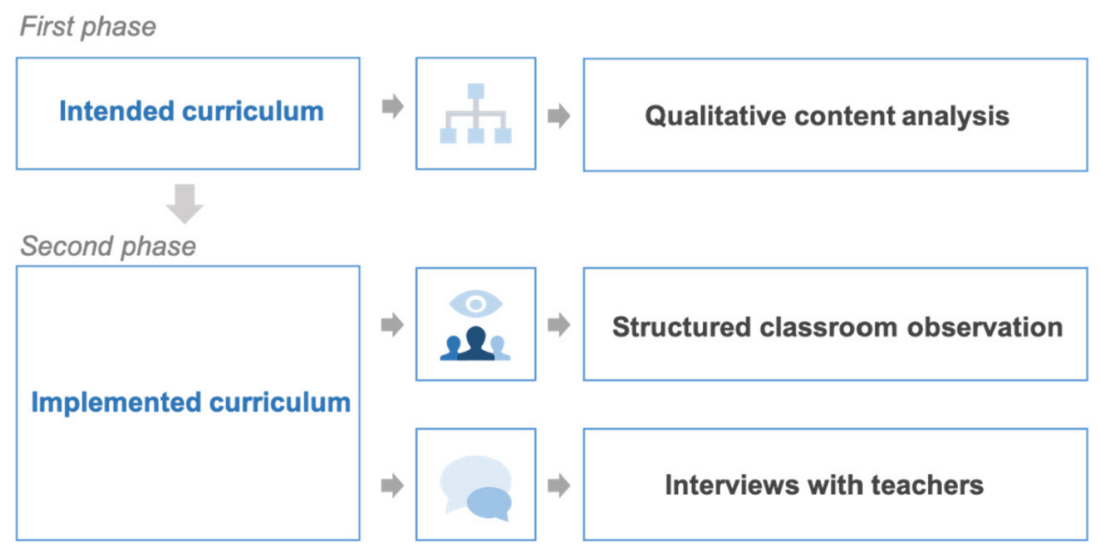

Figure 1: Focus of Different Research Phases and Corresponding Methods

In the first research phase, the embeddedness of the elements of the competence-based approach in target curricular documents from both countries is analyzed and compared, by using a qualitative content analysis method, which is understood as a method for describing selected text meanings through a process of organizing information into categories related to the central research questions, and identifying themes or patterns (Bowen, 2009; Hsieh \& Shannon, 2005; Kuckartz, 2014; Mayring, 2000; Schreier, 2014). Qualitative content analysis has proved to be a well-suited method for curriculum analysis in several studies (Pilz et al., 2016; Levander \& Mikkola, 2009; Malekipour et al., 2017; Pilz \& Li, 2012; Shkedi, 2009). It can be applied to various types of written texts and, therefore, is suitable for analyzing the intended curriculum in our research. The system of categories for the analysis of intended curriculum, was developed with a mixed approach combining both concept-driven categories and data-driven categories (Kuckartz, 2019). 
The second research phase is dedicated to analysis of the implementation of the competencebased approach in teaching and learning processes, by using the methods of structured classroom observation, and interviews with the involved teachers in selected vocational schools in both countries. Classroom observation is seen as a common method in studies of teaching and learning practices, to explore the reality of what occurs in the classroom (Guo \& Pilz, 2020; Wragg, 1999). Structured observation is especially suitable for studies with specific research questions or focus (Phellas et al., 2011), which in our case is the implementation of the competence-based approach. The categories developed in the first research phase are used to build the structured observation instrument, to scrutinize the actual implementation of those elements of the competence-based approach identified from the intended curriculum in real teaching and learning processes. Afterwards, the teachers involved are interviewed with the purpose of reflection on the observed teaching and learning processes, with reference to the competence-based approach. This paper is dedicated to the first phase of the research processes, focusing on developing the instrument for analysis and comparison of intended curriculum.

\section{Theoretical Background}

Two central concepts underlying our research should be briefly clarified.

\subsection{Curriculum}

The concept of curriculum is used as a theoretical basis for the question of planning and implementing educational processes. In the literature on curriculum theory, there is no common definition of curriculum. Referring to the complexity of the curriculum concept, Adamson and Morris (2014) describe curriculum as "multifaceted, operating at a variety of focal points and in diverse manifestations" (p. 310). The word curriculum originates from the Latin for a short running track (Adamson \& Morris, 2014). A variety of curriculum concepts range from a very narrow understanding of curriculum, understood as normative documentation containing educational intentions (European Centre for the Development of Vocational Training, 2010), to vast conceptions, including various levels and representations. An example of the broad definitions is Model of Goodlad et al. (1979), which classifies the curriculum into six classes: Ideal curriculum, formal curriculum, perceived curriculum, operational curriculum, experienced curriculum, and attained curriculum. Van den Akker et al. (2010) proposed a simpler typology of curriculum representations by further developing the model of Goodlad et al. (1979). He distinguished between three broad curriculum representations: Intended, implemented, and attained curriculum. The International Bureau of Education of 
the United Nations Educational, Scientific and Cultural Organization (IBE-UNESCO) also provides definitions of these three curriculum representations.

Among narrower definitions of curriculum, which describe certain aspects of education process, and broader definitions and typologies, covering various aspects of educational processes, experiences and outcomes, for our research we intended to select a curriculum concept which corresponds to the scope of our research question and at the same time which can be general enough to be used in a comparative study and be applied in different national contexts. The threefold classification of the curriculum is chosen as most applicable for our research, because the conceptualization of the first two levels closely covers the focus elements of our main research question, namely planning and implementing the educational processes in VET. More precisely, the definitions from IBE-UNESCO were adopted as working definitions of intended and implemented curricula for our research (see Table 1). The definitions are broad enough and at the same time provide a good orientation for data selection on different stages of the study.

Table 1: Working Definition of Curriculum in CodeVET

\begin{tabular}{|l|l|}
\hline $\begin{array}{l}\text { Intended } \\
\text { Curriculum }\end{array}$ & $\begin{array}{l}\text { "A set of formal documents which specify what the relevant national education authorities and society } \\
\text { expect that students will learn at school in terms of knowledge, understanding, skills, values, and attitudes } \\
\text { to be acquired and developed, and how the outcomes of the teaching and learning process will be assessed. } \\
\text { It is usually embodied in curriculum framework(s) and guides, syllabi, textbooks, teacher's guides, content } \\
\text { of tests and examinations, regulations, policies and other official documents ..." (IBE-UNESCO, 2013). }\end{array}$ \\
\hline $\begin{array}{l}\text { Implemented } \\
\text { Curriculum }\end{array}$ & $\begin{array}{l}\text { "The actual teaching and learning activities taking place in schools through interaction between learners } \\
\text { and teachers as well as among learners, e.g., how the intended curriculum is translated into practice and ac- } \\
\text { tually delivered. Also defined as the 'curriculum in action' or the 'taught curriculum"' (IBE-UNESCO, 2013). }\end{array}$ \\
\hline
\end{tabular}

\subsection{Competence-Based Approach}

Competence-based education, is becoming one of the leading paradigms for modernization of contemporary professional, vocational and continuing education, at both system-level and the level of educational processes (Biemans et al., 2004; Hodge et al., 2019; Wesselink et al., 2010). Broad recognition of the competence-based approach in VET is explained by an expectation that it contributes to narrowing the gap between educational and professional spheres, and allows an easier transition from school to work (Biemans et al., 2004). However, a concept of competence, which underlines the competence-based approach in education, is still very diffuse (Baumeler, 2019; Hodge et al., 2019). There is no universally accepted definition of competence, which can cover a large variety of the ways in which the term is used (Weinert, 2001; Winterton, 2012). Weinert (2001) conducted a study exploring different theoretical approaches to the concept of competence for the Organization for Economic Co-operation and Development (OECD)'s international and interdisciplinary project DeSeCo (Definition 
and Selection of Competencies: Theoretical and Conceptual Foundations). He distinguished nine different ways in which a concept of competence is defined or interpreted theoretically: General cognitive ability, specialized cognitive skills, competence-performance model, modified competence-performance model, motivated action tendencies, objective and subjective self-concepts, action competence, key competencies, and meta-competencies (Weinert, 2001). Boahin et al. (2014) further point out, that different organizations and countries use the same term of competence but conceptualize it differently based on their institutional structures and labor processes. Le Deist and Winterton (2005) argue that national contexts influence understanding of competence; however, Winterton (2012) underlines that even within countries, there are diversities in the understanding and use of competence approaches across sectors or between different education spheres. Consequently, its essential features and modalities within national VET systems and internationally are heterogeneous (Baumeler, 2019). Due to the heterogeneity of the competence concept, no single competence concept was chosen as a basis for the research from the start. Instead, the understanding and conceptualization of the competence-based approach in the English-speaking world, as well as Russian and Chinese theoretical discourses, will be explored and elaborated (see Section 4.1).

\section{Collaborative Development of the Analysis Framework for the First Research Phase}

The development process of the analysis framework for content analysis of intended curriculum represents a complex multistage process, with both deductive and inductive steps, which is presented below in Figure 2. The development process of the analysis framework was carried out collaboratively by the whole research team. 


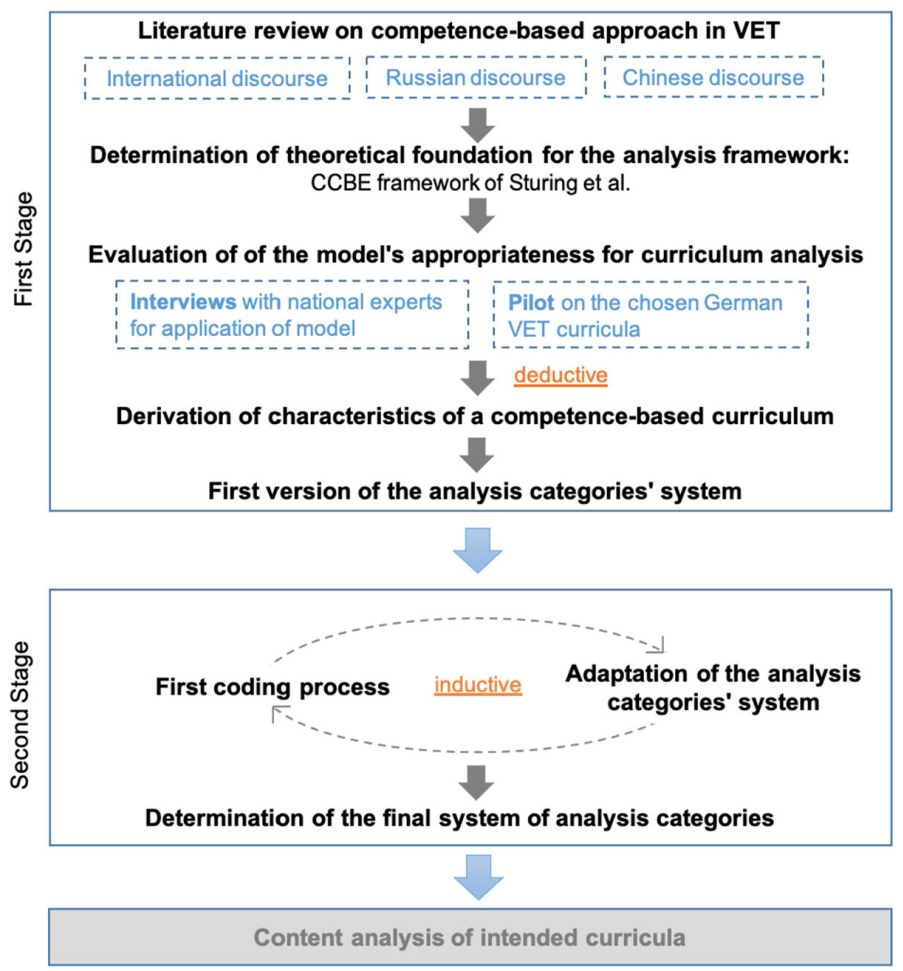

Figure 2: The Development Procedure of the Analysis Framework

\subsection{Building the Analysis Framework}

In the first stage, the whole team, with researchers from Germany, China, and Russia, worked cooperatively to construct the joint analysis framework. The process started with a literature analysis of the international (published in English language), Russian and Chinese discourses on competence-based (vocational) education. The literature analysis included an evidence review, also called systematic review (Gessler \& Siemer, 2020), and a research on various models of competence-based education.

The goal of the evidence review was to identify the main features of the competencebased approach at different curriculum levels in VET from recent scientific discourses on competence-based education. The results of the literature review of international discourse were to build the foundation for the analysis framework development for intended curricula. Furthermore, the results from the analysis of Russian and Chinese discourses aimed to provide the basis for the extension of the analysis framework to target national contexts.

Results gained from the international discourse analysis were evaluated, and several problems regarding their usability for framework development were identified. First, the ar- 
ticles in the sample of international discourse, were mainly from English-speaking countries. Furthermore, in the accumulated results, conceptualizations of a competence-based approach from several countries, in particular from Australia, Netherlands and the USA, were predominant, due to the number of articles in the sample dedicated to them. Therefore, the derived features reflect the international discourse on competence-based education only to a limited extent.

Thus, various models in the international discourse, containing characteristics of competence-based VET, were researched as an alternative foundation for building a curriculum analysis framework. The following models were identified: Watson (1991), Deißinger and Hellwig (2005), Wesselink et al. (2007), Wesselink et al. (2010), Sturing et al. (2011). Owing to space constraints, all models cannot be presented here. Although a relative similarity characterizes these models in respect of their constituent features, the model of Sturing et al. (2011) was assessed by our research team as potentially the most suitable foundation for constructing an analysis framework. Here we should clarify our choice:

The Revised Model of Comprehensive Competence-Based Vocational Education (Revised CCBE Model) of Sturing et al. (2011) represents the result of years of research on competence-based vocational education by a Dutch research community. It was revised several times based on the results of constituent studies, which use various empirical data and methods, and therefore it is characterized by a high validity and credibility. Among the considered models, the Revised CCBE Model is the most comprehensive and validated model for evaluation of the "competentiveness" (Sturing et al., 2011, p. 193) of educational programs with a solid theoretical background.

Furthermore, the Revised CCBE Model was recently applied in other national contexts, for instance in Indonesia (Misbah et al., 2019) and in Ethiopia (Solomon, 2016). The successful utilization of the Revised CCBE Model outside of the Dutch VET context is further argument supporting the choice of the Revised CCBE Model in our research.

Another argument concerns the concept of competence underlying the model, which is oriented on the holistic understanding of competence and social constructivist view of learning (Sturing et al., 2011). Although in both countries researched in this project, Russia and China, there is no unified definition of competence in scientific discourse or educational policy documents, a holistic understanding of competence dominates. In Russian scientific literature on VET, competence is often defined as an integrative whole of knowledge, skills and personal qualities, ensuring professional activity (Goljaeva, 2011; Trofimova, 2013; Zeer \& Symanjuk, 2005). Some others underline experience as another important element of competence (Zeer \& Symanjuk, 2005). Such an understanding of competence is also used in some normative documents in VET. For instance, recently developed methodological recommendations for actualization of educational standards for VET competence are defined as "ability to apply knowledge, skills and practical experience for successful activity in a certain area" 
(The Ministry of Education and Science of the Russian Federation, 2015, p. 2). Under the holistic view in the Chinese context, competence emphasized in the VET field is regarded as the integration of knowledge, skills, and attitudes, embodied in an individual's professional work performance, combined with specific work situations (Chen, 2010; He, 2003; Pang, 2010). In most VET policy documents, competence is usually understood as professional competencies which are referred to as the integration of knowledge, skills, attitudes and physical abilities necessary to perform professional activities (Pang, 2010). Therefore, the concept of competence behind the Revised CCBE Model does not contradict the understanding of competence in the researched countries. Furthermore, the comparison of the features of a competencebased curriculum derived from analysis of national discourses, and the characteristics of competence-based VET of the model, demonstrated a considerable conformity.

Taking all the above-mentioned arguments into account, namely the holistic understanding of competence, the comprehensiveness and credibility of the model, as well as its applicability in different national contexts, this Revised Model of Comprehensive Competence-Based Vocational Education was chosen as the basis for the analysis framework, which however still needs further modification by additional characteristics for Russian and Chinese contexts.

The Revised CCBE Model consists of ten principles of competence-based vocational education (Sturing et al., 2011):

1. The study program is based on core tasks, working processes and competences (the qualification profile).

2. Complex vocational core problems are central.

3. Learning activities take place in different concrete, meaningful vocational situations.

4. Knowledge, skills and attitudes are integrated.

5. Students are regularly assessed.

6. Students are challenged to reflect on their own learning.

7. The study program is structured in such a way that the students increasingly self-steer their learning.

8. The study program is flexible.

9. The guidance is adjusted to the learning needs of the students.

10. In the study program attention is paid to learning, career and citizenship competences.

Initially, these principles represented the analysis categories of the common part of the analysis framework. Its applicability in Chinese and Russian contexts was evaluated through interviews with national experts from both countries in the VET field. Their opinion was, that the analysis framework is applicable, but should be further adapted for country-specific contexts. In addition, a pilot study on selected German VET curricula was carried out to test the applicability of the analysis framework for intended curriculum; results demonstrated 
that the analysis framework could be used for the analysis of intended curriculum. However, in spite the model's comprehensiveness, some of the concepts behind the principles, for instance self-steering or self-reflection are not sufficiently operationalized to be used for our research purpose. Therefore, a further literature review was necessary to operationalize the selected concepts. Furthermore, the direct use of principles as analysis categories was problematic during the pilot study. In this sense, principles should rather serve as a starting point for determining characteristics of the competence-based curriculum which should be analyzed. For this purpose, the analysis categories and their descriptions were formulated, based on the theoretical foundation of the model. Additionally, the country-specific characteristics with corresponding categories added to the joint part of the analysis framework. Finally, the analysis framework was evaluated during the discussions with project partners in both countries.

As a result of the steps described, the first version of the analysis framework was completed. A typical suggested cross-language translation process (Guillemin et al., 1993) was not included in our development process, because the analysis instrument is applied directly in English for the Chinese and Russian curricular documents by the researchers who are native speakers of Chinese and Russian as well as proficient in English.

\subsection{Adapting the Analysis Framework}

In the second stage of the analysis framework development, the developed system of categories was applied to empirical data. After analysis of half of the collected curricular documents, various difficulties in the application of the instrument were identified (see Sections 4.2.1-4.2.4). Therefore, a further adaptation process was required. Compared to other procedures of cross-cultural adaptations of research instruments carried out before instrument application (Gjersing et al., 2010), the majority of adaptation steps in our research were performed during the first application of the developed analysis instrument. The procedure of qualitative content analysis in this study, particularly regarding construction of categories, does not strictly correspond to any procedures presented in the literature on content analysis, but rather represents several ideas and steps combined to best suit the specific methodological requirements of our comparative study (see Figure 3). In this regard, Mayring (2000) emphasized that while conducting a qualitative content analysis, researchers should keep in mind that a research question should take precedence over the proposed steps in the procedure of content analysis. If necessary, the procedure can be adapted to fit the specificity of the research better. 


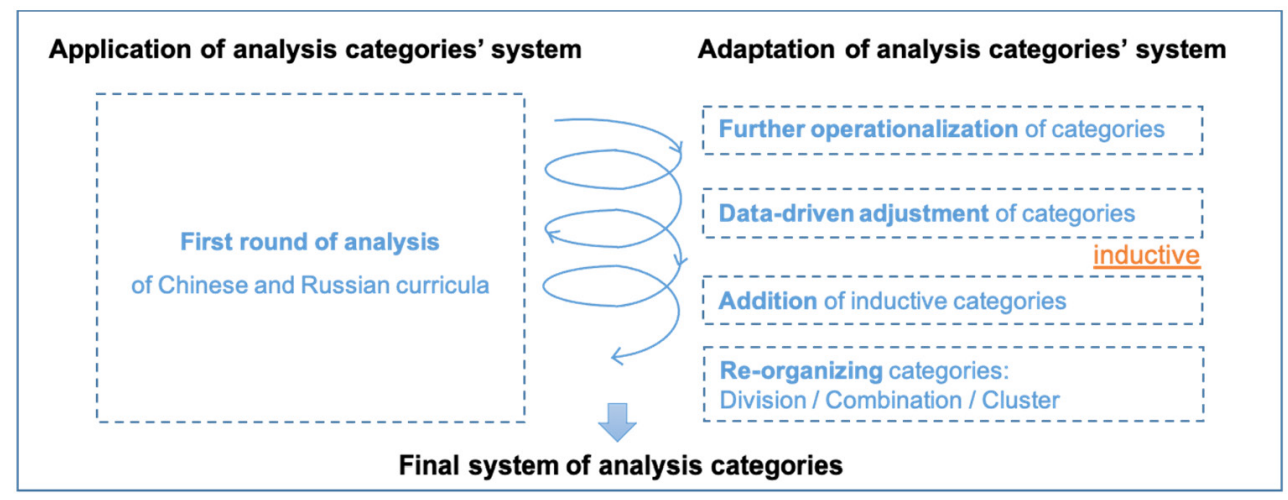

Figure 3: Adaptation Process of the Analysis Framework

Using several examples, different kinds of procedure in the adaptation process of the instrument for the curriculum analysis in our research are presented below.

\subsubsection{Operationalization of Categories Using Additional Literature Research}

Principles and their descriptions, as explained earlier, built a basis for deriving characteristics of the competence-based curriculum, and categories to analyze them, as well as descriptions of the categories. However, we noticed during the first coding round, that descriptions of some categories, especially the ones concerning teaching and learning, were too general and were difficult to apply to the data. The reason for that lay in the insufficient operationalization of the underlying concepts of the principles. The model was not created for the analysis of curricula, neither did it offer comprehensive instructions regarding realization of didactic principles. Therefore, a literature review of the most relevant scholarly sources on the concepts underlying the principles, was conducted. These concepts are: Self-reflection and self-steering in learning, flexible curricula and learner-centered teaching and learning, curriculum integration, life-long learning, citizenship and career competencies. Due to limited space, we will only provide two examples.

\section{Category of Self-Reflection}

The principle of self-reflection in the Revised CCBE model emphasizes that students should be motivated and provided with opportunities to reflect on their learning process and results (Sturing et al., 2011). The reflection practice allows students to understand the connection between specific learning experiences and successful performance in practice (Wesselink et al., 2007). Wesselink et al. (2017) suggest that critical reflection is essential for the development of competences because it facilitates the necessary processes of that deepening and expanding of learning experiences. However, the model does not provide concrete specifications of the didactic implementation of the principle, and implications of the principle for the intended curriculum. 
Through further literature research, the most influential and highly cited literature on the concept of reflective learning (Boud et al., 1985; Boyd \& Fales, 1983; Dewey, 1938; Kolb, 1976) were overviewed to operationalize the concept of self-reflection, for the purpose of our research. Several didactic implications were derived from these publications and are reflected in the set of indicators for the description of the category self-reflection (see Table 2).

Table 2: Common Category of Self-Reflection and its Description

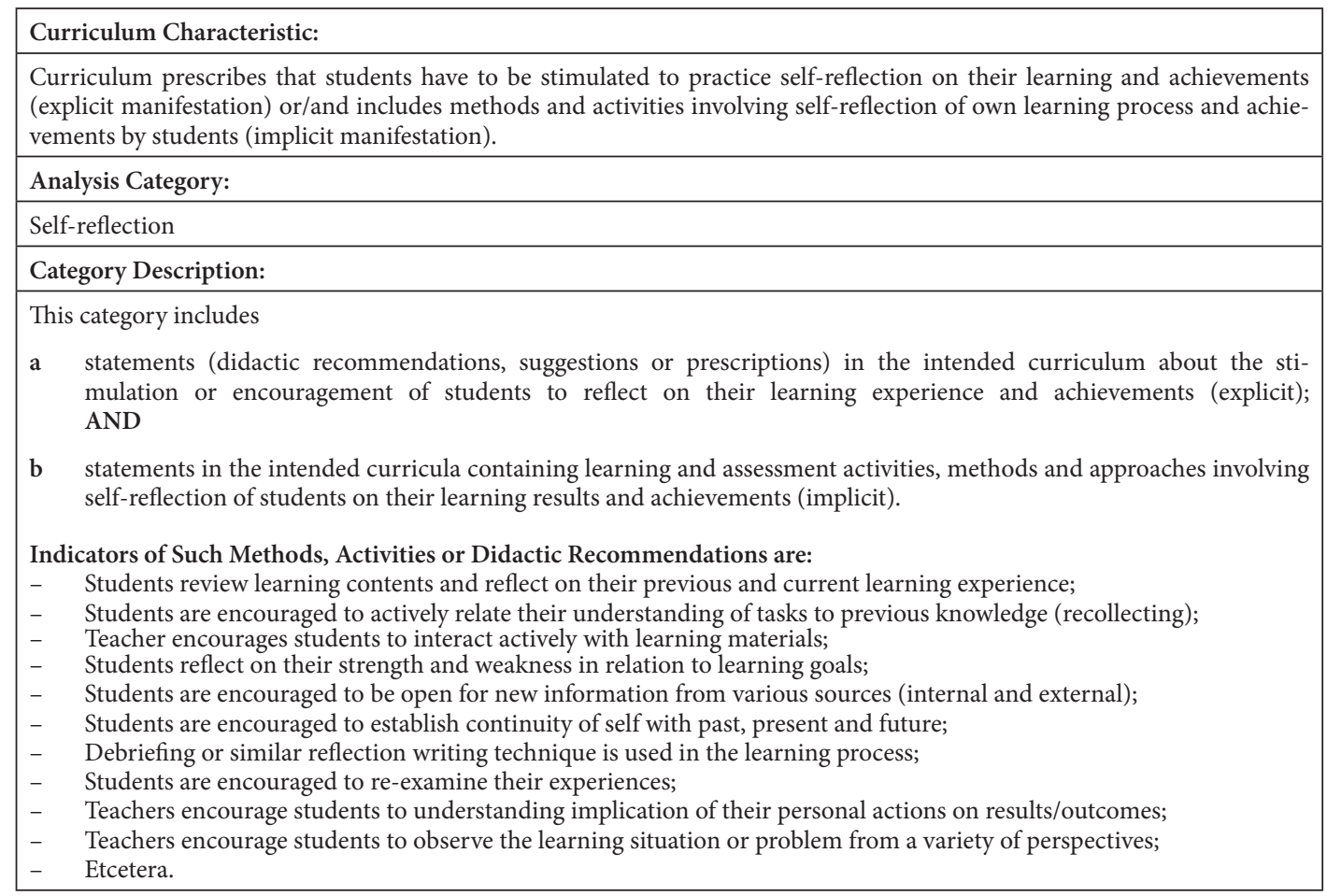

\section{Category of General Competencies}

The principle underlines the importance of the development of the learning, career and citizenship competencies during the study program (Sturing et al., 2011). The general understanding of these competencies, which can be derived from the theoretical background of the model, is that they are not the competencies needed for a specific occupation but required for continuous personal and career development as well as for successful work and social life. However, the authors of the model did not explicitly define or operationalize the competence groups described in the principle. Therefore, for our research purposes, a further operationalization was required.

We started with a literature review of the concepts of learning, citizenship and life-long learning competencies. In the effort to operationalize the learning, career and citizenship 
competencies we faced a conceptual problem. Operationalizing these competencies separately based on different resources would lead to the partial loss of the comprehensive objective behind the principle. Furthermore, the theoretical differentiation between two competency groups, learning and career competencies, was not totally clear.

Around the globe on national and supranational levels, there are different concepts of competencies, which can be compared to the understanding of the competence groups presented by the authors of the model. These groups of competencies are, in their meaning, similar to the concept of general, key, generic, transferable, multidisciplinary or crosscurricular competencies, which have been widely discussed in the research and political discourses for some time. We considered and compared the usage of different frameworks: The framework Key Competencies and New Literacy (Dobryakova et al., 2020), the framework of Key Competencies for Lifelong Learning developed at the European Union level (Council of the European Union, 2018), as well as the international and interdisciplinary framework of the key competencies developed within the project DeSeCo (OECD, 2005). Although the frameworks represent conceptually suitable options for our research, and are internationally developed, there were some limitations to their applicability. The European framework is characterized especially by its regional distinctions in respect to its development and application. Although the DeSeCo model was internationally developed, Russia and China were not involved in this process. The framework Key Competencies and New Literacy was recently developed by an international team of researchers and experts from eight countries including Russia and China, who analyzed more than 180 national and international frameworks of competencies, was reviewed (Dobryakova et al., 2020). We considered this framework as a potentially suitable option for our research due to the participation of Russia and China in the development process. However, as with other above-mentioned frameworks, it represents a conceptual instrument, developed theoretically, based on other existing frameworks and still not implemented in the educational contexts of Russia and China.

After consideration of advantages and disadvantages of utilizing the described options, it was decided to concentrate on the essential idea behind the principle, namely on the importance of development of the non-vocational competencies along with occupation-specific competencies. In that way, the main idea of the principle is reflected in our analysis framework. At the same time, a further enlargement of the category system through utilization of a specific conceptual framework could be avoided. The term general competencies was pragmatically selected for our research. To operationalize the term general competencies, the overarching objective of this competencies group described in the model was brought into focus, instead of using a classification or building various sub-groups of competencies (see Table 3). 
Table 3: Common Category of General Competencies and its Description

\begin{tabular}{|l|}
\hline Curriculum Characteristic: \\
\hline In the curriculum the attention is paid to the development of various general competencies. \\
\hline Analysis Category: \\
\hline General competencies \\
\hline Category Description: \\
\hline $\begin{array}{l}\text { This category includes statements, referring to the development of competencies which are not directly connected to the } \\
\text { chosen profession/vocation, but useful for the professional success and fulfillment in any kind of future professional activity, } \\
\text { for the personal fulfillments as well as for life-long learning. This group includes all competencies in the curriculum, which } \\
\text { are not directly connected to the chosen vocation. }\end{array}$ \\
\hline
\end{tabular}

\subsubsection{Data-Driven Adjustment of Categories}

During the first coding process, researchers were often confronted with the problem that a category description or name did not fit the data well, and had to be adjusted. The step of further development and adjustment of categories based on data is typical for a qualitative analysis procedure (Kuckartz, 2014). However, while working with material in different languages in our research, every change in the common system of categories needed to be discussed and approved by a team to fit for coding in both contexts, instead of making adjustments independently. For this, questionable coding examples from Russian and Chinese curricular documents were translated into English and discussed, until researchers found a consensual solution on how a category should be modified to fit both data. Additionally, a joint coding guideline containing coding examples from Russian and Chinese curricula in original language, and their translations into English, was created and constantly updated, during the first coding process (see Table 4). Through this approach the subjective reasoning of researchers, which is otherwise not available due to the language aspect, could be made more transparent for the whole team. 
Table 4: Example of Coding Guideline

\begin{tabular}{|c|c|c|c|c|c|}
\hline $\begin{array}{l}\text { Analysis } \\
\text { Category }\end{array}$ & $\begin{array}{l}\text { Categories' } \\
\text { Description }\end{array}$ & $\begin{array}{l}\text { Anchor Examples } \\
\text { Russia }\end{array}$ & Coding Rules & $\begin{array}{l}\text { Anchor Examples } \\
\text { China }\end{array}$ & Coding Rules \\
\hline $\begin{array}{l}\text { 1a. } \\
\text { Qualification } \\
\text { Profile }\end{array}$ & $\begin{array}{l}\text { a1. } \\
\text { Statements } \\
\text { indicating that } \\
\text { qualification } \\
\text { profile is used } \\
\text { in the } \\
\text { curriculum } \\
\text { development } \\
\text { process }\end{array}$ & $\begin{array}{l}\text { "Forms and methods of } \\
\text { assessment of } \\
\text { professional compe- } \\
\text { tence formation, } \\
\text { indicators, and assess- } \\
\text { ment criteria are } \\
\text { developed in } \\
\text { accordance with the } \\
\text { requirements of } \\
\text { professional standards." } \\
\text { "Формы и } \\
\text { методы оценки } \\
\text { сформированности } \\
\text { профессиональных } \\
\text { компетенций, } \\
\text { показатели и } \\
\text { критерии оценки } \\
\text { разработаны в } \\
\text { соответствии с } \\
\text { требованиями } \\
\text { профессиональных } \\
\text { стандартов." }\end{array}$ & $\begin{array}{l}\text { Coded: } \\
\text { Mentioning of } \\
\text { professional } \\
\text { standards of } \\
\text { any kind }\end{array}$ & $\begin{array}{l}\text { "The accounting } \\
\text { training programs } \\
\text { are [...] closely } \\
\text { combining the } \\
\text { requirements of } \\
\text { talents training } \\
\text { in the accounting } \\
\text { professional quali- } \\
\text { fication profile." } \\
\text { "会计专业紧 } \\
\text { 密结合了会计 } \\
\text { 职业资格对人 } \\
\text { 才培养的要 } \\
\text { 求." }\end{array}$ & $\begin{array}{l}\text { Coded: } \\
\text { Mentioning any kind } \\
\text { of use of vocational } \\
\text { qualifica-tions or } \\
\text { national vocational } \\
\text { standards in } \\
\text { curriculum }\end{array}$ \\
\hline
\end{tabular}

Categories derived from Principle 4 of the model demonstrate an example of such adjustment. The principle emphasizes that knowledge, skills and attitudes, which are elements of competence, should be integrated in the learning and assessment processes (Sturing et al., 2011). Two initially formulated categories were: Integration of knowledge, skills and attitudes in learning and integration of knowledge, skills and attitudes in the assessment. Lauterbach (2018b) points out that while developing analysis instruments, as well as the analysis process, and interpretation of results in comparative studies on VET, researchers should take into careful consideration that the same or similar terms and assignments can have different connotations in different national contexts. During the coding process it became clear that elements of competence can vary in different national contexts. In Russian curricula documents, a competence does not include an attitude aspect. Instead, in addition to knowledge and skills it contains an element practical experience. Therefore, a slight semantic adjustment of formulations of corresponding categories was made, by replacing the part of the text "knowledge, skills and attitudes" with "elements of competence". Curriculum characteristics and corresponding analysis categories became more universal for analysis without changing the original core idea of the principle. 


\subsubsection{Reorganizing Categories}

\section{Categories and Sub-Categories}

During the coding process, the need to reorganize, split or combine some categories was identified. One example represents curriculum characteristics $1 \mathrm{a}$ and $1 \mathrm{~b}$ and their corresponding analysis categories. One of the characteristics derived from the first principle was initially formulated as "The study program is based on core tasks, working processes and competences (the qualification profile)". The first round of coding demonstrated the need to modify the characteristic and analysis category. In curriculum qualification profiles for instance, professional standards in Russian curricula, were often mentioned. In addition, segments indicating use of competencies, working processes or tasks from the labor market in the curriculum design were found. However, in many cases, especially in Chinese curricula, it was unclear from the data, whether the mentioned working processes, competencies or tasks were derived from qualification profiles. To avoid misleading interpretations, it was decided to separate this characteristic into two elements, without loss of the essential meaning of the principle-synchronization of the study program with the labor market through its design: (1) Qualification profile is used in curriculum development and (2) curriculum is based on working processes, tasks and/or competencies.

Another example of reorganization is the flexibility characteristic. It was operationalized based on the results of a literature review in terms of adaptability and accessibility, which demonstrate the degree to which a curriculum can be adjusted to meet students' needs and capabilities (Jonker et al., 2020). Adaptability is connected to flexibility regarding the what and how aspects of learning, while accessibility of curriculum concerns flexibility in the where and when aspects of education. Based on these four elements, sub-categories were built: Content flexibility, flexibility of pedagogies and didactics, location flexibility and time flexibility. During the coding process it became clear that along with elements of flexibility, corresponding to the built categories, curriculum flexibly was often formulated explicitly. In order to include such elements, and avoid further enlargement of the analysis framework, categories were turned into indicators of flexibility, along with the explicit prescription of it. This allowed a more efficient coding process and helped to minimize the complexity of the analysis framework.

\section{Constructing Clusters}

The first coding process demonstrated the difficulty in effectively orienting in the system of more than 30 common and country-specific categories. Application of the thematic clusters, which classified curriculum characteristics and corresponding categories into four big groups, allowed a more structured and organized category system. The clusters were adopted from the previous research conducted by Misbah et al. (2019), who used the system of clustering to optimize the presentation of their study results: Cluster 1: Competencies, core tasks, 
and linkages to the labor market; Cluster 2: Teaching and learning in competence-based education; Cluster 3: Competence assessment, and Cluster 4: Career, lifelong learning and citizenship competencies. All country-specific categories were integrated in the cluster system.

\section{Comparing and Combing National Categories}

Country-specific characteristics, derived from the analysis of national discourses on competence-based curricula, and not coinciding with the models' principles, were added to the analysis framework before the first coding process. They were further adjusted based on the analyzed data, and assigned to clusters. A comparison of categories and coded units demonstrated that some of the Russian and Chinese characteristics and categories could be combined. So, three common additional characteristics were added to the analysis framework and assigned to clusters. For instance, a common characteristic "Labor market experts or actors are involved in the curriculum development, evaluation and implementation (including assessment)" was formulated and integrated into Cluster 1. Accordingly, the analysis category involvement of labor market actors and experts was created with two corresponding sub-categories: (1) Involvement in curriculum development and evaluation and (2) involvement in curriculum implementation.

\subsubsection{Adding Categories Inductively}

Finally, several country-specific curriculum characteristics and categories were added to the analysis category system inductively during the first round of analysis. These units were added to analysis frameworks either through a direct indication of the connection of their idea with the competence-based approach, or because they were suited to the clusters' overarching themes. For instance, a curriculum characteristic "Curriculum prescribes that educators responsible for a professional part of the program, should have professional experience in the field they teach" and the corresponding category were added to Cluster 1 as an additional Russian category (see Table 5). The above-mentioned curriculum characteristic was added to Cluster 1 due to the reasoning that teachers who possess professional experience of the labor market in the occupation for which learners are being prepared, are familiar with the real vocational practice and problems, and therefore, can contribute to the approximation of learning processes with their practical insights. 
Table 5: Russian Country-Specific Category of Professional Experience of Educators

\begin{tabular}{|l|}
\hline Curriculum Characteristic: \\
\hline $\begin{array}{l}\text { Curriculum prescribes that educators responsible for professional part of the program should have professional experience } \\
\text { in the field they teach. }\end{array}$ \\
\hline Analysis Category: \\
\hline Professional experience of educators \\
\hline Category Description: \\
\hline $\begin{array}{l}\text { This category includes statements in the curriculum indicating that educators have to possess a professional experience in } \\
\text { organizations, the direction of activity of which corresponds to the field of professional activity of future graduates. }\end{array}$ \\
\hline
\end{tabular}

A further example of an inductively added category representing a country-specific maincategory for analysis of Chinese curricula, was named "Requirements for team of educators". It was developed from curriculum prescriptions concerning specific requirements expected of the team of educators for professional courses, which are aimed to strengthen the connection between the study program and working practice. In similar vein to the reasoning of the Russian example described above, characteristics and corresponding analysis categories of this curriculum were added because they are seen in the curriculum as a means to contribute to the objective of orienting the program toward practice (see Table 6). The elements were afterwards added to Cluster 1 . However, we decided not to combine these two inductively developed curriculum characteristics, and corresponding analysis categories in common country-specific units, as in the above-described example of the characteristic (see Table 5), due to a broader meaning of the Chinese curriculum characteristic.

Table 6: Chinese Country-Specific Category of Requirements for Team of Educators

\begin{tabular}{|l|}
\hline Curriculum Characteristic: \\
\hline $\begin{array}{l}\text { Curriculum prescribes different requirements expected of a team of educators responsible for the professional courses in } \\
\text { study program, to strengthen the connection between the study program and real work: } \\
-\quad \text { Double qualifications and work experience requirements for school teachers; } \\
-\quad \text { Required involvement of experts from company. }\end{array}$ \\
\hline Analysis Category: \\
\hline Requirements for team of educators \\
\hline Category Description: \\
\hline $\begin{array}{l}\text { This category includes statements, recommendations or requirements about the double qualification of teachers, who are } \\
\text { involved in teaching this study program; statements or requirements describing that the teachers for professional courses } \\
\text { should have enough working or practical experience in his/her teaching area; statements or requirements that the teacher } \\
\text { team should be set up with both experts from enterprise or industry (part-time) and the well-educated teachers with practical } \\
\text { experience (full-time). }\end{array}$ \\
\hline
\end{tabular}




\section{$5 \quad$ Reflection and Conclusion}

As Pilz et al. (2020) showed, a research process conducted by an international team is usually different from the one done by a single researcher or a team from one country. The development of the analysis framework for comparing Russian and Chinese curricular documents within our study is an example of how a comparative instrument for an international multi-language study can be cooperatively developed in an international team. Although some steps are not unique and characteristic to comparative research or the procedure of qualitative content analysis, definite issues were connected to the particularities of conducting an international comparative study with a team of researchers from different countries. In this sense, we would like to reflect on our experience of collaborative development and adaptation of an analysis framework, as well as on methodological challenges we described in this paper.

In the context of this research, the instrument for curriculum analysis was first developed deductively, based on a comprehensive review of English, Russian and Chinese literature and further adapted, based on the empirical material. This process of adaptation of the analysis instrument was a laborious iterative multistep procedure, and was conducted collaboratively. In this approach, the organisation of the research process and language aspects played an essential role. The importance of language proficiency of the researchers conducting international comparative research was emphasised by Bereday (1961) more than half a century ago (Pilz, 2012). The sequence described above, and the combination of steps in the process of framework creation, application and adaptation for national contexts, were only possible because team members are native speakers of Russian or Chinese languages, and at the same time are also proficient in English, which is the common language of the team. So, in our research, the analysis instrument was developed and applied in the English language. Furthermore, a linguistic competence in Russian and Chinese allowed the team direct access to literature and data in the original languages. Thus, it was possible to complement a common analysis framework with country-specific dimensions, based on the analysis of corresponding national scientific discourses, to conduct interviews with national experts for framework validation, as well as to perform a data-driven adaptation of the analysis framework, based on analysis of the original (national) curricular documents. The translation of the analysis framework from Russian and Chinese language before its application was not necessary. Neither was a translation of the curricular document into English, as the common language, necessary, with the exception of coding examples. Potential problems caused by flawed translation could therefore be avoided. However, assuring the concepts' equivalence while applying a developed framework in national contexts was still a challenge. Working with the jointly operationalized concepts instead of translated terms, which can cause different connotations in different national contexts (Lauterbach, 2018b), helped researchers assure each concept's equivalence while applying a developed framework in national contexts. 
A data-driven adaptation of the instrument was only possible through continuous intensive communication, since none of the team members could speak both languages of the target countries and therefore could not directly access all the analysed material. To partly overcome this given limitation of the study, the team discussed every required adaptation step in the common part of the analysis instrument and made each decision together. This approach enabled the data-driven adjustments of the common coding frame (see Section 4.2.2) or combining similar national-specific categories in common categories (see Section 4.2.3).

In our experience, the relatively small size of the research team proved to be an important factor, as this helped facilitate the comprehensive iterative adaptation process. The two team members primarily responsible for the second stage of analysis framework development, namely its adaptation during the first round of coding, could work closely during the whole process. Although the researchers belonged to German universities, which were initiators of the research, they had the advantage of being native speakers of the Chinese and Russian languages. Continuous support from research colleagues from target countries during the whole adaptation process, for instance through a discussion of doubtful coding, allowed the team to combine both outsider and insider perspectives to evaluate and reflect on adjustments made (Pilz et al., 2020). Creation of the common coding guidelines, containing examples in original languages and their translated versions from both countries, supported the transparency of the process for all participants, and improved the calibration of coding logic within the team. The effects of researchers' ethnocentric perspective, which are often emphasised in the research community (Lauterbach, 2018a; Mason, 2014; Pilz, 2012), could be reduced.

During the collaborative development of the analysis framework for the research, we also experienced some organisational and methodological limitations of the process. First, such a close cooperative process creates co-dependency between researchers, and requires a certain degree of synchronization of their working. Thus, an iterative adaptation process of the analysis instrument required a concurrent application and testing of changes in the coding frame on data and the following discussion (see Section 4.2.3). Second, the procedure is time-consuming. Probably, a more time-efficient procedure could be achieved through an alternative approach by adapting the created framework separately for every targeted national context. However, that would result in two considerably different analysis frameworks, which would eventually make the follow-up comparison of the results from both countries more complex, and less transparent. Finally, a framework consisting of joint and country-specific analysis categories can become very voluminous and complex. Therefore, its utilization can be very challenging for researchers, since it requires simultaneous consideration of many categories. Alternatively, it is possible to divide the framework into manageable parts and go through the material several times. To avoid such implications, we came to some pragmatic decisions to combine main categories into clusters, and optimize the number of categories by converting selected sub-categories into a description of one main category, which was helpful for the research team. 
To conclude, we would like to emphasize that a cooperative and iterative framework development and adaptation process has many advantages, but also some challenges. The analysis framework finally developed, represents an instrument that is, on the one hand, well-adapted to each national context, and on the other hand, allowing a comparison of results along the same dimensions of analysis, in our case, elements of a competence-based approach in curriculum. In our research, such an approach was only possible due to the continuous intensive communication and collaboration of team members who were responsible for different national contexts, and constant reflection of the process.

However, we would like to emphasize that the intention of this paper was not to offer a universal recommendation for developing and adapting the analysis framework for an international study. Instead, based on reflection on our experience, we plead for a flexible approach that allows the research team to use their full potential and maximize the benefits of outsider and insider perspectives, language competencies, and organizational opportunities.

\section{Acknowledgement}

The project described here is funded by the German Federal Ministry of Education and Research (BMBF) as "Competence Development in VET (CodeVET)" (Ref no. 01BF18001).

\section{References}

Adamson, B., \& Morris, P. (2014). Comparing curricula. In M. Bray, B. Adamson \& M. Mason (Eds.), Comparative education research (pp. 309-332). Springer International Publishing. https://doi. org/10.1007/978-3-319-05594-7

Baumeler, C. (2019). Competence-based vocational education and training and its cultural context sensitivity. European Education, 51(1), 1-15. https://doi.org/10.1080/10564934.2017.1344503

Bereday, G. Z. F. (1961). Theorie und Methoden der vergleichenden Erziehungswissenschaft. In W. Brezinka (Ed.), Weltweite Erziehung. Festgabe für Friedrich Schneider zum 80. Geburtstag (1st ed., pp. 139-162). Herder.

Biemans, H., Nieuwenhuis, L., Poell, R., Mulder, M., \& Wesselink, R. (2004). Competence-based VET in the Netherlands: Background and pitfalls. Journal of Vocational Education \& Training, 56(4), 523538. https://doi.org/10.1080/13636820400200268

Billett, S. (2011). Vocational education: Purposes, traditions and prospects. Springer Science; Business Media. https://doi.org/10.1007/978-94-007-1954-5

Boahin, P., Eggink, J., \& Hofman, A. (2014). Competency-based training in international perspective: Comparing the implementation processes towards the achievement of employability. Journal of Curriculum Studies, 46(6), 839-858. https://doi.org/10.1080/00220272.2013.812680

Boud, D., Keogh, R., \& Walker, D. (1985). Reflection: Turning experience into learning. Kogan Page. https://doi.org/10.4324/9781315059051

Bowen, G. A. (2009). Document analysis as a qualitative research method. Qualitative Research Journal, 9(2), 27-40. https://doi.org/10.3316/QRJ0902027 
Boyd, E. M., \& Fales, A. W. (1983). Reflective learning. Journal of Humanistic Psychology, 23(2), 99-117. https://doi.org/10.1177/0022167883232011

Chen, P. (2010). Zhi ye neng li guan yan bian de li shi luo ji ji qi li lun shu ping - ji yu neng li ben wei jiao yu yu pei xun fa zhan de yan jiu [The historical relation of the value of professional competence evolution and narrating and reviewing on the value of professional competence-basing on the developing of competency-based education and training]. Zhong Guo Zhi Ye Ji Shu Jiao Yu [Chinese Vocational and Technical Education], 6, 54-57.

Council of the European Union. (2018). Proposal for a council recommendation on key competences for lifelong learning - Adoption. Official Journal of the European Union, 61, 1-13. https://eur-lex.europa. eu/legal-content/EN/TXT/?uri=OJ:C:2018:189:TOC

Deißinger, T., \& Hellwig, S. (2005). Structures and functions of competence-based education and training (CBET): A comparative perspective. Internationale Weiterbildung und Entwicklung InWEnt. https:// kops.uni-konstanz.de/bitstream/handle/123456789/12147/Structures_and_Functions_of_Competence_based.pdf?sequence $=1$

Dewey, J. (1938). Experience and education. Collier Books; Macmillan.

Dobryakova, M., Seel, N., Moss, G., Barannikov, K., Remorenko, I., \& Froumin, I. (2020). Ramka universal'nyh kompetentnostej i novoj gramotnosti [Framework of key competences and new literacy]. In I. Froumin, M. Dobryakova, J. Hautamäki, G. Moss, N. Seel, K. Barannikov, \& I. Remorenko (Eds.), Universal'nye kompetentnosti i novaja gramotnost': Ot lozungov k real'nosti [Key competences and new literacy: From slogans to reality] (pp. 34-65). National Research University Higher School of Economics.

European Centre for the Development of Vocational Training. (2010). Learning outcomes approaches in VET curricula: A comparative analysis of nine European countries. Publications Office of the European Union. https://www.cedefop.europa.eu/files/5506_en.pdf

Evans, K. (2020). Comparative vocational education and training research: What purposes does it serve? In M. Pilz \& J. Li (Eds.), Comparative vocational education research (pp. 3-19). Springer Fachmedien Wiesbaden. https://doi.org/10.1007/978-3-658-29924-8_1

Fischer, M. (2020). Beyond typologies: Alternative ways of comparing VET systems. In M. Pilz \& J. Li (Eds.), Comparative vocational education research (pp. 23-41). Springer Fachmedien Wiesbaden. https://doi.org/10.1007/978-3-658-29924-8_2

Frommberger, D. (2000). Länderübergreifende Berufsbildungsforschung ohne Curriculumforschung? Erste Überlegungen zur international-vergleichenden Curriculumforschung am Beispiel der kaufmännischen Berufsbildung. Zeitschrift für Berufs- und Wirtschaftspädagogik, 96(3), 458-469.

Gessler, M., \& Siemer, C. (2020). Umbrella review: Methodological review of reviews published in peerreviewed journals with a substantial focus on vocational education and training research. International Journal for Research in Vocational Education and Training, 7(1), 91-125. https://doi.org/10.13152/ IJRVET.7.1.5

Gjersing, L., Caplehorn, J. R. M., \& Clausen, T. (2010). Cross-cultural adaptation of research instruments: Language, setting, time and statistical considerations. BMC Medical Research Methodology, 10(1), 13-23. https://doi.org/10.1186/1471-2288-10-13

Goljaeva, N. (2011). Kompetentnostnyj podhod v realizacii ocenki kachestva podgotovki vypusknikov uchrezhdenij srednego professional'nogo obrazovanija [Competence approach in the implementation of quality assessment of training of graduates of secondary vocational education institutions]. Integracija Obrazovanija [Education Integration], 4, 20-24. 
Goodlad, J. I., Klein, M. F., \& Tye, K. A. (1979). The domains of curriculum and their study. In J. I. Goodlad (Ed.), Curriculum inquiry: The study of curriculum practice (pp. 43-76). McGraw-Hill.

Grollmann, P. (2009). Comparative research on technical and vocational education and training (TVET) - Methodological considerations. In F. Rauner \& R. Maclean (Eds.), Handbook of technical and vocational education and training research (pp. 253-259). Springer.

Guillemin, F., Bombardier, C., \& Beaton, D. (1993). Cross-cultural adaptation of health-related quality of life measures: Literature review and proposed guidelines. Journal of Clinical Epidemiology, 46(12), 1417-1432. https://doi.org/10.1016/0895-4356(93)90142-n

Guo, H., \& Pilz, M. (2020). A comparative study of teaching and learning in German and Chinese vocational education and training schools: A classroom observation study. Research in Comparative and International Education, 15(4), 391-413. https://doi.org/10.1177/1745499920959150

$\mathrm{He}, \mathrm{Z}$. (2003). Lun neng li yu neng li ben wei zhi ye jiao yu [Discussion on competence and competencebased vocational education]. Jiao Yu Ke Xue [Education Science], 4, 47-48.

Hodge, S., Mavin, T., \& Kearns, S. (2019). Hermeneutic dimensions of competency-based education and training. Vocations and Learning, 13, 27-46. https://doi.org/10.1007/s12186-019-09227-y

Hsieh, H.-F., \& Shannon, S. E. (2005). Three approaches to qualitative content analysis. Qualitative Health Research, 15(9), 1277-1288. https://doi.org/10.1177/1049732305276687

International Bureau of Education of the United Nations Educational, Scientific and Cultural Organization. (2013). Glossary of curriculum terminology. http://www.ibe.unesco.org/en/glossary-curriculumterminology

Jonker, H., März, V., \& Voogt, J. (2020). Curriculum flexibility in a blended curriculum. Australasian Journal of Educational Technology, 36(1), 68-84. https://doi.org/10.14742/ajet.4926

Kolb, D. A. (1976). Management and the learning process. California Management Review, 18(3), 21-31. https://doi.org/10.2307/41164649

Kosmützky, A., Nokkala, T., \& Diogo, S. (2020). Between context and comparability: Exploring new solutions for a familiar methodological challenge in qualitative comparative research. Higher Education Quarterly, 74(2), 176-192. https://doi.org/10.1111/hequ.12255

Kuckartz, U. (2014). Qualitative text analysis: A guide to methods, practice and using software. SAGE Publications Ltd. https://doi.org/10.4135/9781446288719

Kuckartz, U. (2019). Qualitative text analysis: A systematic approach. In G. Kaiser \& N. Presmeg (Eds.), Compendium for early career researchers in mathematics education (pp. 181-197). Springer International Publishing. https://doi.org/10.1007/978-3-030-15636-7_8

Lauterbach, U. (2003a). Vergleichende Berufsbildungsforschung: Theorien, Methodologien und Ertrag am Beispiel der vergleichenden Berufs- und Wirtschaftspädagogik mit Bezug auf die korrespondierende Disziplin comparative education/vergleichende Erziehungswissenschaft (1st ed.). Nomos-Verl.-Ges.

Lauterbach, U. (2003b). Vergleichende Berufsbildungsforschung und Vergleichende Erziehungswissenschaft als korrespondierende Disziplinen? Zeitschrift für Berufs- und Wirtschaftspädagogik, 99(4), 514-535.

Lauterbach, U. (2018a). Vergleichende Berufsbildungsforschung als Bestätigung für Stereotypen? In P. Grollmann, D. Frommberger \& U. Lauterbach (Eds.), Internationale Weiterbildung, Austausch, Entwicklung: Vol. 9. Internationales Handbuch der Berufsbildung (pp. 26-29). Bertelsmann.

Lauterbach, U. (2018b). Vergleichende Berufsbildungsforschung und Vergleichsstruktur im IHBB. In P. Grollmann, D. Frommberger \& U. Lauterbach (Eds.), Internationale Weiterbildung, Austausch, Entwicklung: Vol. 9. Internationales Handbuch der Berufsbildung (pp. 30-33). Bertelsmann. 
Lauterbach, U., \& Mitter, W. (1998). Theory and methodology of international comparisons. In European Centre for the Development of Vocational Training. (Ed.), Vocational education and training - The European research field background report - Volume II. Office for Official Publications of the European Communities. https://www.cedefop.europa.eu/files/RR1_Lauterbach.pdf

Lauterbach, U., \& Mitter, W. (2018). Konzeption des internationalen Handbuchs der Berufsbildung. In P. Grollmann, D. Frommberger \& U. Lauterbach (Eds.), Internationale Weiterbildung, Austausch, Entwicklung: Vol. 9. Internationales Handbuch der Berufsbildung (pp. 18-24). Bertelsmann.

Le Deist, F. D., \& Winterton, J. (2005). What is competence? Human Resource Development International, 8(1), 27-46. https://doi.org/10.1080/1367886042000338227

Levander, L. M., \& Mikkola, M. (2009). Core curriculum analysis: A tool for educational design. The Journal of Agricultural Education and Extension, 15(3), 275-286. https://doi.org/10.1080/13892240903069785

MacKenzie, J., \& Polvere, R.-A. (2009). Tvet glossary: Some key terms. In R. Maclean \& D. Wilson (Eds.), International handbook of education for the changing world of work: Bridging academic and vocational learning (pp. 59-76). Springer Netherlands. https://doi.org/10.1007/978-1-4020-5281-1_4

Malekipour, A., Hakimzadeh, R., Dehghani, M., \& Zali, M. R. (2017). Content analysis of curriculum syllabus for the educational technology discipline based on entrepreneurial competencies. Interdisciplinary Journal of Virtual Learning in Medical Sciences, 8(4). https://doi.org/10.5812/ijvlms.62156

Mason, M. (2014). Comparing cultures. In M. Bray, B. Adamson \& M. Mason (Eds.), Comparative education research (pp. 165-196). Springer International Publishing. https://doi.org/10.1007/978-3-319-05594-7

Mayring, P. (2000). Qualitative content analysis. Forum: Qualitative Social Research, 1(2). https://doi. org/10.17169/FQS-1.2.1089

McDonald, L. (2012). Educational transfer to developing countries: Policy and skill facilitation. Procedia - Social and Behavioral Sciences, 69, 1817-1826. https://doi.org/10.1016/j.sbspro.2012.12.132

Ministry of Education and Science of the Russian Federation. (2015). Metodicheskie rekomendasii po aktualizasii deystvuyushix federal'nix gosudarstvennix obrazovatel'nix standartov srednego professional'nogo obrazovaniya suchetom prinimaemix professional'nix standartov [Methodological recommendations for actualization of the current federal state educational standards for VET in accordance with the adopted professional standards]. The Ministry of Education and Science of the Russian Federation.

Misbah, Z., Gulikers, J., Dharma, S., \& Mulder, M. (2019). Evaluating competence-based vocational education in Indonesia. Journal of Vocational Education \& Training, 6(5), 1-28. https://doi.org/10.1080/ 13636820.2019.1635634

Organization for Economic Co-operation and Development. (2005). Definition and selection of competencies: Executive summary. DeSeCo. https://www.deseco.ch/bfs/deseco/en/index/02.html

Pang, S. J. (2010). Zhi ye jiao yu shi yu zhong de zhi ye neng li yan jiu [Study on competence development of learner in the view of vocational education] [Doctoral dissertation, Tianjin University].

Parreira do Amaral, M. (2015). Methodologie und Methode in der international vergleichenden Erziehungswissenschaft. In M. Parreira do Amaral \& S. K. Amos (Eds.), New frontiers in comparative education: Vol. 2. Internationale und vergleichende Erziehungswissenschaft: Geschichte, Theorie, Methode und Forschungsfelder (1st ed.). Waxmann.

Phellas, C. N., Bloch, A., \& Seale, C. (2011). Structured methods: Interviews, questionnaires and observation. In C. Seale (Ed.), Researching society and culture (pp. 181-205). Sage.

Phillips, D. (2009). Aspects of educational transfer. In R. Cowen \& A. M. Kazamias (Eds.), International handbook of comparative education (pp. 1061-1077). Springer Netherlands. https://doi. org/10.1007/978-1-4020-6403-6_67 
Pilz, M. (2012). International comparative research into vocational training: Methods and approaches. In M. Pilz (Ed.), The future of vocational education and training in a changing world (pp. 561-588). VS Verlag für Sozialwissenschaften. https://doi.org/10.1007/978-3-531-18757-0_30

Pilz, M., Harris, R., Zenner-Höffkes, L., \& Zirkle, C. (2020). Undertaking comparative VET research in international teams: The example of exploring recruitment and training cultures in SMEs in Germany, Australia and the United States. In M. Pilz \& J. Li (Eds.), Comparative vocational education research (pp. 291-309). Springer Fachmedien Wiesbaden. https://doi.org/10.1007/978-3-658-29924-8_17

Pilz, M., Krisanthan, B., Michalik, B., Zenner, L., \& Li, J. (2016). Learning for life and/or work: The status quo of pre-vocational education in India, China, Germany and the USA. Research in Comparative and International Education, 11(2), 117-134. https://doi.org/10.1177/1745499916637173

Pilz, M., \& Li, J. (2012). What teachers in pre-vocational education should each and what they actually teach: A comparison of curricula and teaching in Germany and China. Research in Comparative and International Education, 7(2), 226-247. https://doi.org/10.2304/rcie.2012.7.2.226

Pilz, M., \& Li, J. (2020). Comparative vocational education research. Springer Fachmedien Wiesbaden. https://doi.org/10.1007/978-3-658-29924-8

Raivola, R. (1985). What is comparison? Methodological and philosophical considerations. Comparative Education Review, 29(3), 362-374. https://doi.org/10.1086/446527

Schreier, M. (2014). Varianten qualitativer Inhaltsanalyse: Ein Wegweiser im Dickicht der Begrifflichkeiten. Forum qualitative Sozialforschung / Forum: Qualitative Social Research, 15(1).

Shkedi, A. (2009). From curriculum guide to classroom practice: Teachers' narratives of curriculum application. Journal of Curriculum Studies, 41(6), 833-854. https://doi.org/10.1080/00220270902927030

Solomon, G. H. (2016). Towards competence-based technical-vocational education and training (TVET) in Ethiopia [Doctoral dissertation, Wageningen University].

Sturing, L., Biemans, H. J. A., Mulder, M., \& De Bruijn, E. (2011). The nature of study programmes in vocational education: Evaluation of the model for comprehensive competence-based vocational education in the Netherlands. Vocations and Learning, 4(3), 191-210. https://doi.org/10.1007/s12186-011-9059-4

Trofimova, N. (2013). Integracija vospitanija i obuchenija v kolledzhe [Integration of education and training in a college]. Obrazovaniem I Samorazvitie [Education and Self-development], 2(36), 76-79.

Van den Akker, J., Fasoglio, D., \& Mulder, H. (2010). A curriculum perspective on plurilingual education. Council of Europe.

Watson, A. (1991). Competency-based vocational education: Is this the answer? The Vocational Aspect of Education, 42(114), 133-145. https://doi.org/10.1080/10408347308003621

Weinert, F. E. (2001). Concept of competence: A conceptual clarification. In D. S. Rychen \& L. H. Salganik (Eds.), Defining and selecting key competencies (pp. 45-65). Hogrefe \& Huber.

Wesselink, R., Biemans, H., Gulikers, J., \& Mulder, M. (2017). Models and principles for designing competence-based curricula, teaching, learning and assessment. In M. Mulder (Ed.), Competence-based vocational and professional education: Bridging the worlds of work and education (pp. 533-553). Springer International Publishing. https://doi.org/10.1007/978-3-319-41713-4_25

Wesselink, R., Biemans, H., Mulder, M., \& Elsen, E. (2007). Competence-based VET as seen by Dutch researchers. European Journal of Vocational Training, 40, 38-51.

Wesselink, R., Dekker-Groen, A. M., Biemans, H. J. A., \& Mulder, M. (2010). Using an instrument to analyse competence-based study programmes: Experiences of teachers in Dutch vocational education and training. Journal of Curriculum Studies, 42(6), 813-829. https://doi.org/10.1080/00220271003759249 
Winterton, J. (2012). Varieties of competence: European perspective. In M. Pilz (Ed.), Research. The future of vocational education and training in a changing world (1st ed., pp. 455-480). Springer VS.

Wragg, E. C. (1999). An introduction to classroom observation (2nd ed.). Routledge.

Zeer, J., \& Symanjuk, J. (2005). Kompetentnostnyj podhod k modernizacii professionalnogo obrazovanija [Competence approach to modernization of professional education]. Vysshee Obrazovanie [Higher Education], 4, 23-30.

\section{Biographical Notes}

Pujun Chen is a research assistant and PhD student at the Chair of Economics and Business Education at the University of Cologne in Germany. Her research interests are international comparative research in VET with the focus on China, competence-based education, economics education and curriculum research.

Anastasia Goncharova is research assistant and $\mathrm{PhD}$ student at the Department of Vocational Education and Training at the University of Osnabrück in Germany. Her research areas include international research in VET, competence-based education and curriculum research.

Prof. Dr Matthias Pilz is Professor of Economics and Business Education at the University of Cologne in Germany and Director of the German Research Center for Comparative Vocational Education and Training (G.R.E.A.T.). His research interests are in international comparative research in VET, transitions from education to employment, and teaching and learning.

Prof. Dr Dietmar Frommberger is Professor for Research on Vocational Education and Training at the University of Osnabrück in Germany. His research interest focuses on international comparative research in VET.

Dr Junmin Li is a researcher and lecturer at the Chair of Economics and Business Education at the University of Cologne in Germany. Her research interests are in international comparative research in VET, school development, evaluation research and learning instruction.

Olga Romanova is a researcher at the Centre for Vocational Education and Skills Development, National Research University Higher School of Economics in Moscow, Russia. Her research interests include vocational education and training, key competences, vocational curricula and school-to-work transition.

Yueru Lin is a research assistant and $\mathrm{PhD}$ student of the Institute of Vocational and Adult Education at the East China Normal University in Shanghai, China. Her research interests include vocational education and training, comparative education and curriculum research. 